\title{
Managing and Maintaining Flatted Buildings: Some Anglo-Scottish Comparisons
}

\author{
$L u X u^{*}$
}
A. BACKGROUND
(1) The legislation of 2004
(2) The late arrival of the DMS
B. MANAGEMENT
(1) The importance of management
(2) Owners' associations and the TMS
C. MAINTENANCE
(1) TMS

(a) The absence of a positive duty to maintain

(b) An example from case law

(c) The Scottish Law Commission's four factors

(2) DMS and Commonhold

D. OCCUPIERS' LIABILITY

E. DMS AND COMMONHOLD COMPARED

(1) The bodies corporate

(2) Conduct standard for directors and managers

(3) Dispute resolution

F. CONCLUSION

On 1 June 2009 the long-awaited Development Management Scheme ("DMS") came to life in Scotland. ${ }^{1}$ The DMS is a statutory but optional scheme for the management and maintenance of developments such as housing estates and flatted buildings. In the

\footnotetext{
* Lecturer, Norwich Law School, University of East Anglia. The author is grateful to Professors Kenneth Reid and C G van der Merwe for comments and suggestions.

${ }^{1}$ See Title Conditions (Scotland) Act 2003 pt 6; the Title Conditions (Scotland) Act 2003 (Development Management Scheme) Order 2009, SI 2009/729; and the Title Conditions (Scotland) Act 2003 (Commencement No 2) Order 2009, SSI 2009/190. The Development Management Scheme (henceforth DMS) is set out in sch 1 of SI 2009/729. An extensive commentary on the DMS can be found in pt 8 of the Scottish Law Commission's Report on Real Burdens (Scot Law Com No 181 (2000), available at www.scotlawcom.gov.uk). See also K G C Reid and G L Gretton, Conveyancing 2009 (2010) 000-000. The DMS was originally prepared as a scheme for tenements, known as Management Scheme B: see Scottish Law Commission, Report on the Law of the Tenement (Scot Law Com No 162 (1998)) pt 6.
} 
latter context it creates an alternative to the Tenement Management Scheme ("TMS") which, since 2004, has provided a set of default rules to supplement whatever provision is made in the title deeds. ${ }^{2}$ The two schemes are mutually exclusive: where the DMS is selected, the TMS does not apply to any extent. ${ }^{3}$

This article compares the DMS to the TMS as well as to the commonhold system in England and Wales which was introduced by the Commonhold and Leasehold Reform Act 2002. It argues that, if used effectively by conveyancers and developers, the DMS holds advantages over both systems.

\section{A. BACKGROUND}

\section{(1) The legislation of 2004}

Apartment ownership has a long history, dating back well before modern society. ${ }^{4}$ In Scotland, for example, tenement buildings were known in medieval times, especially in Edinburgh. The development of a law suitable for these structures was problematic in many jurisdictions. The concept of apartment ownership was unknown in Roman law, while in the Common Law world the concept of "flying freehold" was no better welcomed. As apartment buildings became more common, providing much-needed accommodation in increasingly crowded cities, so statutory regulation seemed the obvious answer. By the 1980s legislation had been passed in France, Belgium, Germany, New Zealand, Australia, South Africa, and the USA among others. In fact many of these countries had up to three generations of apartment ownership statutes, responding to the deficiencies of the first attempts and to the changing needs of society.

This left Great Britain looking increasingly isolated. As late as the end of the last century, neither England nor Scotland had an apartment ownership statute. There were plenty of apartment buildings, of course, and many more were being built, but the law in both jurisdictions was largely static and, arguably, ineffective. In England, due to the problems associated with owning a flying freehold and enforcing positive covenants, flats had usually to be leased rather than owned - a system which, as the government pointed out, was "fundamentally flawed". ${ }^{5}$ In Scotland, where there had been almost no legal development on the issue for the best part of the twentieth century; conveyancing practice and the widespread use of real burdens effectively side-stepped the lack of formal sources of law. As pointed out by the Scottish Law Commission in 1998, the law itself was "based on a handful of reported cases mixed with disputed extrapolations of professors". ${ }^{6}$ To conveyancers schooled in the art of

\footnotetext{
${ }^{2}$ Tenements (Scotland) Act 2004 s 4. The Tenement Management Scheme (henceforth TMS) is set out in sch 1 of the Act. See further K G C Reid and G L Gretton, Conveyancing 2004 (2005) 121-150; W M Gordon and S Wortley, Scottish Land Law, $3^{\text {rd }}$ edn, vol 1 (2009) 469-497.

${ }^{3}$ Tenements (Scotland) Act 2004 s 4(2).

${ }^{4}$ See C G van der Merwe, “Apartment Ownership" (1994), in International Encyclopaedia of Comparative Law vol VI.

${ }^{5}$ Commonhold and Leasehold Reform: Draft Bill and Consultation Paper (Cm 4843: 2000, available at http://www.communities.gov.uk/publications/housing/reformdraftbill) 107. ${ }^{6}$ Scottish Law Commission, Law of the Tenement (n 1) para 2.1.
} 
drafting deeds of conditions, the system was both workable and comprehensible, as long as one kept in mind the underlying framework of real burdens and common interest. To those who actually lived in tenements, however - estimated as one quarter of the Scottish population ${ }^{7}$ - the law was largely inaccessible.

For a long time, and in both jurisdictions, there had been calls for statutory reform. In Scotland the initial response was slow. Although the Scottish Law Commission published a discussion paper back in $1990,{ }^{8}$ a final report (with draft bill) was not issued until 1998, ${ }^{9}$ and it took a further six years for a bill based on the Commission's work to be introduced to the new Scottish Parliament. Once the bill was in Parliament, however, matters progressed rapidly. The Tenements (Scotland) Act 2004 received Royal Assent on 22 October 2004 and came into force barely a month later, on 28 November. This was also the day on which the feudal system of land tenure was abolished, ${ }^{10}$ as well as being the commencement date for much of the Title Conditions (Scotland) Act 2003.

In England the history was longer and the pace slower still. The idea of legislative intervention began with the report of the Wilberforce Committee in $1965,{ }^{11}$ and the Law Commission proposed a system of "commonhold" as early as $1987 .{ }^{12}$ Such was the expectation of its impact that the government decided to postpone indefinitely the reform on freehold covenants recommended by the Law Commission in $1984 .{ }^{13}$ Yet a draft government bill had to wait until $2000 .{ }^{14}$ This was finally enacted as the Commonhold and Leasehold Reform Act 2002, and the Act came into force on 27 September 2004, shortly before the corresponding legislation in Scotland. And so it was that, within a period of two months in 2004, both England and Scotland welcomed their first statute on apartment ownership.

\section{(2) The late arrival of the DMS}

Despite the coincidence of timing, however, the Scottish tenement reform in 2004 was not intended as an equivalent of commonhold in England. In a manner similar to statutes in other jurisdictions, the English Commonhold Act created a new form of apartment ownership, and if an apartment building is to become a commonhold, it has to be registered as such under the statutory regime. The reform does not therefore affect any building, new or existing, unless some positive step is taken. ${ }^{15}$ As a result, almost all apartment buildings in England have remained in leasehold despite the

${ }^{7}$ Scottish Executive, Tenements (Scotland) Bill Consultation (2003, available at http://www.scotland.gov.uk/consultations/housing/tsbc-00.asp) 7.

${ }^{8}$ Scottish Law Commission, Discussion Paper on the Law of the Tenement (Scot Law Com DP No 91 (1990).

${ }^{9}$ Scottish Law Commission, Law of the Tenement (n 1).

${ }^{10}$ Abolition of Feudal Tenure etc (Scotland) Act $2000 \mathrm{~s} 1$.

${ }^{11}$ Report of the Committee on Positive Covenants Affecting Land (Cmnd 2719: 1965).

${ }^{12}$ Law Commission, Commonhold: Freehold Flats and Freehold Ownership of other Interdependent Buildings (Cm 179: 1987).

${ }^{13}$ Law Commission, Easements, Covenants and Profits à Prendre (Law Com CP No 186 (2008)) para 1.15.

${ }^{14}$ Commonhold and Leasehold Reform (n 5).

${ }^{15}$ For the practical difficulties in respect of existing buildings being converted into commonhold, see P F Smith, "The purity of commonholds" (2004) Conv 194. 
Commonhold Act. By contrast, the Scottish Tenements Act, or more precisely the Tenement Management Scheme ("TMS") introduced by that Act, is automatically applied to all apartment buildings in Scotland, whether built before or after 2004. The only exception is where the Development Management Scheme ("DMS") applies, in which case that scheme replaces the TMS. Although the Title Conditions (Scotland) Act 2003 made provision for the DMS, the scheme could not be enacted in full because one of its central features, the owners' association, was a 'business association" and hence reserved to the Westminster parliament. ${ }^{16}$ The Scottish reform therefore remained incomplete until 1 June 2009, when the DMS was finally brought into effect with the help of a statutory instrument from the UK government. ${ }^{17}$

With the DMS now in place, the developers or owners of a Scottish tenement building have three choices: they can do nothing and rely entirely on the TMS, or they can carry on the tradition of drafting their own title conditions, leaving the TMS (as a default regime) to fill in any gaps, or they can adopt the new DMS. As at 1 June 2009 the TMS applied to all 830,000 tenement flats in Scotland. The expectation is that some of these existing buildings and many of the newly built developments will start to adopt the DMS. In this sense the DMS faces a similar challenge to that which has confronted English commonhold since 2004, namely to convince developers and owners that it is a specialised, more convenient and effective system for the management and maintenance of flatted buildings. But it is not enough to win the battle of ideas: the DMS is unlikely to be widely used unless it is possible to overcome inertia and a reluctance to venture into the unknown.

So far, English commonhold has failed the test to a rather alarming extent. Developers of new buildings have shied away from innovation and continued to favour the "fundamentally flawed" but thoroughly familiar device of leasehold tenure. The original estimate by the government at the time of legislation was that there might be as many as 6,500 new commonhold schemes registered per year. ${ }^{18}$ As it turned out, five years after the full commencement of the statute, by 2009 the total number of registered commonhold in England and Wales failed to reach even twenty! ${ }^{19}$ When this is compared with the 100,000 or so long leasehold estates being created every year, the gross unpopularity of commonhold becomes all too obvious. Naturally, this unpopularity had been the subject of discussion and speculation in legal and property periodicals. ${ }^{20}$ The superficial consensus is that commonhold, while a good system, is

${ }^{16}$ Scotland Act 1998 Sch 5 pt II C1. At C1 "business association" is defined widely as "any person (other than an individual) established for the purpose of carrying on any kind of business, whether or not for profit". As "business" includes "the provision of benefits to the members of an association", it will therefore presumably extend to the management of flatted buildings for the benefit of owners.

${ }^{17}$ Title Conditions (Scotland) Act 2003 (Development Management Scheme) Order 2009, SI 2009/729.

${ }^{18}$ Commonhold Proposals for Commonhold Regulations: A Lord Chancellor's Department Consultation Paper (October 2002, available at http://www.dca.gov.uk/consult/common/commonhold.htm) Annex F Part I para 9. ${ }^{19} \mathrm{R}$ Megarry and W Wade, The Law of Real Property, $7^{\text {th }}$ edn, by C Harpum, S Bridge and M Dixon (2008) para 33-001 put the total number by March 2008 at 17. An inquiry at the Land Registry in April 2009 revealed that, somehow, the number had gone down to 16 .

${ }^{20}$ See for example, S Rowe, "Uncommon title" (2007) Estates Gazette \#0704 136; J Driscoll, "Whatever happened to commonhold?" (2008) New Law Journal 1137. 
not pushed hard enough by the government or sufficiently appreciated by developers and consumers. Be that as it may, the harsh reality is that some twenty years of legislative endeavour has resulted in a list of commonhold developments that will barely fill one side of A4.

The DMS can be said to differ from commonhold in that it does not attempt a clean break from the former law and practice. However, there are also many similarities. It is therefore important to consider the possible advantages the DMS may enjoy over the TMS to justify its adoption as well as the lessons which may be learned from the so-far unsuccessful campaign of English commonhold.

\section{B. MANAGEMENT}

\section{(1) The importance of management}

The obvious starting point for assessing a system of apartment ownership is its structure for management. Writing in the early 1990s, Professor van der Merwe concluded that a "properly structured organisation" is necessary for apartment ownership schemes: ${ }^{21}$

$<$ EXT $>$ The community of apartment owners cannot function effectively without a properly structured organisation to handle the many problems and everyday details in keeping the scheme functioning smoothly and efficiently. The inevitable chaos caused by the lack of a central management body is strikingly illustrated by the problems experienced by the earlier types of apartment ownership schemes ... All modern statutes recognise the need of effective management and either compel all apartment owners to participate in the management of the scheme or organise them in a management body for this purpose. $<$ EXT $>$

Within a few years, this approach had been demonstrated in the USA, ${ }^{22}$ Australia, ${ }^{23}$ Canada, ${ }^{24}$ and many other jurisdictions which passed their new generation of apartment ownership statutes. Predictably, English commonhold followed the same path by requiring the establishment of a management body in every commonhold known as the commonhold association. However, in the Tenements (Scotland) Act 2004, such a management organisation was omitted, in anticipation of the

${ }^{21}$ Van der Merwe (n 4) at para 332.

${ }^{22}$ Uniform Common Interest Ownership Act 1994 s 3-101: “A unit owners' association must be organized no later than the date the first unit in the common interest community is conveyed. The membership of the association at all times consists exclusively of all unit owners ...'

${ }^{23}$ Strata Schemes Management Act 1996 (New South Wales) s 8: "(1) On the registration of a strata plan for a strata scheme, there is established an owners corporation for the strata scheme in accordance with Part 2. (2) An owners corporation for a strata scheme has the principal responsibility for the management of the scheme."

${ }^{24}$ Strata Property Act 1998 (British Columbia) s 3: "Except as otherwise provided in this Act, the strata corporation is responsible for managing and maintaining the common property and common assets of the strata corporation for the benefit of the owners." 
Development Management Scheme. This may leave Scottish tenements not under the DMS at a disadvantage.

The TMS is not run by a management body, although one may be provided by the title deeds. Instead it proceeds on the basis of a series of voluntary and formally unrelated "scheme decisions" made by the owners. A scheme decision may be proposed by any owner, and then decided upon by, generally speaking, the majority of all owners. ${ }^{25}$ The onus is on the person who wants a scheme decision to follow the statutory procedures. A decision can be taken by going round doors and counting votes, or there can be a formal meeting. ${ }^{26}$ In the latter case, the owner "must give the other owners at least 48 hours' notice of the date and time of the meeting, its purpose and the place where it is to be held". ${ }^{27}$ Once made, a scheme decision must, as soon as practicable, be notified: ${ }^{28}$

$<$ EXT $>$ (a) if it was made at a meeting, to all the owners who were not present when the decision was made, by such person as may be nominated for the purpose by the persons who made the decision, or

(b) in any other case, to each of the other owners, by the owner who proposed that the decision be made. $<$ EXT $>$

An obvious concern is whether individual owners are sufficiently motivated and knowledgeable to be in the position equivalent to a scheme manager, initiating motions, consulting owners, arranging meetings, and notifying everyone of the result. A further question is whether this commitment can be continued on a regular basis, as may be required for the maintenance of a building which is large and old. The problem is avoided if the owners take a scheme decision to appoint a manager for the building, as they are entitled to do, ${ }^{29}$ or if a manager is provided for under the title deeds, but not all tenements will have managers.

The DMS is quite different in this regard. An owners' association is automatically established on the day that the DMS takes effect. ${ }^{30}$ The association is a sui generis body corporate for the sole purpose of managing the development for the benefit of its members. ${ }^{31}$ More importantly, there is also a person who is charged with the duty of management, who acts as the agent of the association, and who carries out such dayto-day tasks as routine maintenance or consultation with the owners. ${ }^{32}$ Unlike the TMS, where such responsibilities are offloaded on to all owners, the DMS concentrates the management function on a single person, who in practice will usually be a professional manager or factor.

\section{(2) Owners' associations and the TMS}

The absence of an owners' association in the TMS was not overlooked during the legislative process for the Tenements Bill, but an amendment designed to provide one

25 TMS r 2.5 .

26 TMS r 2.7 .

27 TMS r 2.6 .

${ }^{28}$ TMS r 2.9.

29 TMS r 3.1(c).

${ }^{30}$ DMS r 2.1.

${ }^{31}$ DMS rr 2.2, 3.1.

${ }^{32}$ DMS r 4. 
was swept aside on the basis that, as already mentioned, "business associations" (i.e. associations in the form of a body corporate) were beyond legislative competence. ${ }^{33}$ At the time it was thought that the omission might be made good by an order of the UK government under section 104 of the Scotland Act 1998, and in guidance notes published by the Scottish government in November 2005, such an order was still on the agenda although only for buildings with twelve or more flats. ${ }^{34}$ However, although a section 104 order has now provided for the DMS, there is no sign of a matching order in respect of the TMS and it may be that none will now be made.

As it happens, it is quite common for tenements to have a management structure, whether by agreement among the owners or as a result of provisions in the title deeds. This may take the form of a manager or of an (unincorporated) owners' association, or both. At the time of the passing of the legislation, MSPs commented on the value and usefulness of owners' associations and expressed the view that the government should "encourage" their establishment. ${ }^{35}$ The impression given is that, although the issue is formally out of the reach of the Scottish Parliament, it can be dealt with by individual owners on their own initiative. ${ }^{36}$ But comforting as that understanding appears to be, it overlooks the fact that any such body is fundamentally different from the associations found in the DMS, in commonhold, or in other jurisdictions. A nonDMS association in Scotland is unincorporated and so not an independent legal entity. Although in theory it may be established as a company, in practice, as the Scottish Law Commission observed, "the degree of formality and regulation involved are out of scale with the relatively humble functions performed by the association". ${ }^{37}$

A number of disadvantages follow from the unincorporated status. First, such an association cannot, as in other jurisdictions, own the common parts of buildings.

Secondly, there is no visible entity which can represent all the owners in litigation or for other purposes. This may cause inconvenience when an outsider comes to deal with the individual or collective interests in the scheme. An example is where a buyer seeks to discover whether there is outstanding liability for repairs in respect of the flat being purchased. The solution offered by the Tenements (Scotland) Act - the registration by other owners in the building of a notice of potential liability for $\operatorname{costs}^{38}$ - has been criticised since its last-minute introduction, ${ }^{39}$ but the details are beyond the scope of this paper. In practice the tenement's manager or factor - if there is one may be prepared to deal with the issue and provide information relating to potential liability, to the best of his understanding but without legal effect. By contrast, the manager in a building subject to the DMS is under a statutory obligation to produce a

${ }^{33}$ Scottish Parliament, Official Report, Justice 2 Committee, cols 866-867 (15 June 2004).

${ }^{34}$ Scottish Government, Management and Maintenance of Common Property (2005, available at $h t t p: / / w w w . s c o t l a n d . g o v . u k / P u b l i c a t i o n s / 2005 / 11 / 2194749 / 47506)$ para 86.

${ }^{35}$ Scottish Parliament, Official Report cols.4680-4682 (8 Jan 2004).

${ }^{36}$ Scottish Parliament, Official Report, Justice 2 Committee, cols 866-867 (15 June 2004).

${ }^{37}$ Scottish Law Commission, Law of the Tenement (n 1) para 6.8.

${ }^{38}$ Tenements (Scotland) Act 2004 ss 12, 13.

${ }^{39}$ D B Reid, "The Tenements (Scotland) Act 2004", in R Rennie (ed), The Promised Land: Property Law Reform (2008) at para 6-60. 
certificate, and liability cannot exceed the amount which is stated there. ${ }^{40}$ Under commonhold, too, provision is made for a "commonhold unit information certificate". 41

Thirdly, and most importantly, an unincorporated association can neither shield owners from liabilities nor shoulder any duty or responsibility. Writing in 1990, Professor Reid drew attention to the difficulty of identifying the person against whom a statutory notice for repairs should be served. ${ }^{42}$ After almost two decades of legislative effort and one landmark statute, the law is still in no better position to solve that problem in respect of non-DMS developments.

\section{MAINTENANCE}

\section{(1) TMS}

\section{(a) The absence of a positive duty to maintain}

The Scottish Law Commission regarded the failure to provide a proper mechanism for decision-making and management as the defect "above all" to which the former law was subject. ${ }^{43}$ The position under that law was summarised by Professor McDonald as follows: ${ }^{44}$

$<$ EXT $>[\mathrm{T}]$ here seems to be no duty on any proprietor of a flat in a tenement to carry out regular inspections in order to ensure that repairing and other comparable obligations are implemented. Further, the duty of each proprietor to implement his common law obligation under the law of the tenement does not imply an absolute duty. If damage to the tenement results, there is therefore no liability on any individual proprietor unless negligence or culpa can be established. $<$ EXT $>$

After the enactment of the Tenements (Scotland) Act 2004, Professor Rennie seemed to be satisfied by the legislative achievement in this regard: ${ }^{45}$

$<$ EXT $>$ The thrust of the [Tenement Management] Scheme is to place obligations on owners in relation to maintenance, whether relating to parts in exclusive or common ownership. The effect may therefore be to impose obligations on flat owners that they did not have in the past. $<$ EXT $>$

While, however, there are unarguably new obligations as a result of the Act, such obligations do not extend beyond contributing to the cost of maintenance when a decision to carry out such maintenance is made. ${ }^{46}$ There is no provision anywhere in the statute to the effect that a person has the responsibility of proper maintenance and management of the tenement building. A proprietor is merely obliged to pay for such

40 Title Conditions (Scotland) Act 2003 (Development Management Scheme) Order 2009 art 16.

${ }^{41}$ Commonhold Regulations 2004 (SI 2004/1829) Sch 3 para.4.7.1-4.7.7.

${ }^{42}$ K G C Reid, "The law of the tenement: three problems' (1990) 35 JLSS 368.

${ }^{43}$ Scottish Law Commission, Law of the Tenement (n 1) para 2.30.

${ }^{44} \mathrm{C}$ Waelde (ed), Professor McDonald's Conveyancing Opinions (1998) 52.

${ }^{45}$ R Rennie, "Last piece of the jigsaw" (2004) 49 JLSS March/26.

46 TMS r 4. 
maintenance when, and more importantly if, it is instructed by a scheme decision made by a majority of owners. Unless matters have deteriorated to the point where support or shelter for the building is at risk - a situation which is now governed by the statute rather than the common law principle of common interest ${ }^{47}-$ an individual owner, or owners falling short of a majority, cannot require repairs to parts of the building.

The criterion for decision is thus not whether a repair is necessary or reasonable but simply whether a majority of owners is in favour of it. Interestingly, if a decision to repair is made by the majority, any of the dissenting minority may challenge the decision in the sheriff court. ${ }^{48}$ However, application to the court is a shield and not a sword, and a judge cannot make a new decision on behalf of the owners. ${ }^{49}$ So if only a minority of owners wants repairs to be made, nothing can happen even if the repairs are necessary and reasonable. Consequently, the key functionality of the statute is dependent on the majority of owners in a building holding a reasonable or sensible view on maintenance and repairs.

The Scottish Law Commission explained its position on the topic in this way: ${ }^{50}$

$<$ EXT $>[\mathrm{M}]$ aintenance is a right but it is not a duty. We do not suggest that owners be placed under a positive obligation to maintain the tenement. The building is theirs, and what they do with it is a matter for their own collective decision. In any event, a positive obligation to maintain is difficult to reconcile with the principle of majority decision-making. The freedom of the majority to decide becomes illusory if, because of the existence of a positive obligation, they must always decide in a particular way. $<$ EXT $>$

During the legislative process, the Scottish Law Commission's confidence on this matter was seen as a sharp contrast to the position adopted by its English counterpart. ${ }^{51}$ Of course maintenance obligations are often imposed in the title deeds by real burden - something which could not be achieved in English law due to the prohibition of positive covenants. Nonetheless the Scottish Law Commission's statement is essentially based on the notion that owners, or a majority of them, can do what they like with their buildings. In other words, ownership is the right to abuse as well as to use. The argument bears an unexpected resemblance to English law's rejection of positive covenants even for maintenance of buildings, namely that law (and equity) cannot force an owner to "put his hand into his pocket" just because he happens to be the owner of a building, even if the building may fall down if it is not properly repaired. ${ }^{52}$

Official statistics cast doubt on whether owners know best. According to the 2002 Scottish House Condition Survey, in the owner-occupied sector, 27\% of houses and $40 \%$ of tenement flats had at least one element in a state of "urgent disrepair" ${ }^{53} \mathrm{In}$ other words, more than a quarter of house owners, who occupy their own, structurally independent, houses and are in a position to decide on maintenance, do not actually

${ }^{47}$ Tenements (Scotland) Act 2004 ss 8, 9.

48 Tenements (Scotland) Act 2004 s 5.

${ }^{49}$ Reid \& Gretton, Conveyancing 2004 (n 2) 133.

${ }^{50}$ Scottish Law Commission, Law of the Tenement (n 1) para 5.45.

${ }^{51}$ P F Smith, "Owning flats: Scottish or English style?" (2000) 5 SLPQ 36 at 45.

${ }^{52}$ Haywood v Brunswick Permanent Benefit Building Society (1881-2) LR 8 QBD 403 at 409 per Cotton LJ.

${ }^{53}$ Explanatory Notes, Housing (Scotland) Act 2006, para 6. 
carry out urgently needed repairs. The percentage was higher for flat owners, probably due to the difficulties of carrying out maintenance before the 2004 Act. One can easily envisage situations where such "unreasonable" owners are in the majority in a tenement building. In fact, the problem of disrepair seems to have worsened in the last few years. According to figures released in 2009, 79\% of all Scottish housing stock has at least one element of disrepair, $48 \%$ are in need of urgent repair, and $72 \%$ of dwellings have disrepair to critical elements. ${ }^{54}$

Considering the complexity of individual interests and the conflicting priorities of owners, the situation where a majority may block reasonable and necessary maintenance becomes far more than simple statistics or probabilities. Professor Halliday dealt with a rather interesting dispute which came to his attention long before the current reform. ${ }^{55}$ Due to the physical structure and layout of a particular development, some of the owners on one side of a tower block were unable to receive a colour television signal in their flats and had to rely instead on a communal aerial and relay system. When the time came for this system to be maintained or upgraded, almost all of the owners who could receive a signal independently of the system voted against the proposal. Bearing in mind that the TMS may be modified by obsolete title conditions - such as where ground floor shops are expected to subsidise residential

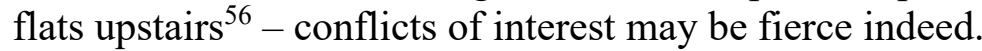

\section{(b) An example from case law}

In the only reported case on the Tenements (Scotland) Act since its commencement more than five years ago, the absence of a duty of maintenance led to a rather extraordinary battle for majority control. In PS Properties (2) Ltd v Callaway Homes $L t d,{ }^{57}$ the tenement building was of typical construction, with two shops on the ground and four residential flats on top of the shops, two on each storey. According to the TMS, therefore, there were six units each with one vote, so that a decision regarding repairs could be made by securing at least four votes in favour. ${ }^{58}$ Both shops were owned by PS Properties Ltd. Two of the four flats were owned by Callaway Homes Ltd. The remaining two flats were separately owned. In 2005 the common stair of the property needed repairing. Some temporary, remedial works were carried out, presumably paid for by the flat owners. However, more permanent and expensive repairs were recommended by structural engineers. Callaway served notice to everyone else in the building with a view to reaching a scheme decision on the repairs. One of the other flat-owners agreed, which in combination with Callaway's votes amounted to three votes out of six, just one short of a majority. PS Properties, on the other hand, said that if extensive works were to be carried out, the location of the entrance should be moved from the front of the building to the side,

\footnotetext{
${ }^{54}$ Scottish Government, Scottish House Condition Survey: Key Findings for 2008 (2008, available at http://www.scotland.gov.uk/Publications/2009/11/23090958/5) section 4.3.

${ }^{55}$ D J Cusine (ed), The Conveyancing Opinions of J M Halliday (1992) 507-511.

${ }^{56}$ Reid (n 39) at 6-55.

${ }^{57}$ [2007] CSOH 162, 2007 GWD 31-526.

${ }^{58}$ The focus of the litigation was on the calculation of votes in the particular layout of the tenement building in question. This is beyond the context of this article. For more details, see R Rennie, "Counting the cost in tenements" 2009 SLT (News) 137.
} 
presumably for the benefit of their shops. As Callaway would not agree to this, PS Properties would not agree to the repairs. The deadlock was broken when the owner of the final flat put it on the market. Although PS Properties entered into negotiations to purchase, the flat was actually bought by Callaway, thus giving them the necessary majority

The events described more resemble a hostile takeover at the London Stock Exchange than a tale of ordinary tenement life in Stirling. Buying a neighbour's flat is certainly not an everyday strategy for repairing the staircase. In any apartment building, as the case shows, different owners will have different priorities and demands. Some will rely on stairs or lifts; others may place emphasis on external appearance; others still may favour communal facilities such as television aerials. In the absence of a positive duty, repairs are left to the preferences or conscience of the parties.

\section{(c) The Scottish Law Commission's four factors}

In rejecting a positive duty to repair, the Scottish Law Commission emphasised four factors that, in the Commission's view, minimised the problem of obtaining consent. ${ }^{59}$ In the first place, the concept of common interest, now restated in statutory form, ${ }^{60}$ would solve any problems relating to support or shelter. For if the roof was leaking or a load-bearing wall was in need of strengthening, the owner would have to carry out the repair and look to the others for a contribution. The difficulty, however, is that some parts of the building are not related to either support or shelter. The common passage and stairs in PS Properties is an obvious and important example, but there are others such as security entrance systems, the back green, or decorative items.

The Scottish Law Commission's next point was that "titles quite frequently contain real burdens which impose a positive obligation of maintenance". ${ }^{61}$ But if the TMS is intended as a background law, making provision where titles are silent, this can hardly be accepted as a plausible argument for silence on the subject of maintenance.

Thirdly, the Commission drew attention to public law regulation in this area, for example the power of local authorities to require or instruct repairs. Indeed, in a significant new development, local authorities can now impose a whole programme of maintenance on tenements by means of a maintenance order. ${ }^{62}$ While, however, the impact of such maintenance orders will be seen in time, it is hardly convincing to argue that because public authorities may have relevant powers, the law should not provide individual owners with the possibility of insisting on necessary repairs. The differences between a public law power and a property law duty are all too obvious. Further, the extent to which voluntary repairs are supplemented by public law measures will in practice depend on the resources made available to local government for this purpose. ${ }^{63}$

${ }^{59}$ Scottish Law Commission, Law of the Tenement (n 1) paras 5.46-5.50.

${ }^{60}$ Tenements (Scotland) Act 2004 ss 7-10.

${ }^{61}$ Scottish Law Commission, Law of the Tenement (n 1) para 5.47.

${ }^{62}$ Housing (Scotland) Act 2006 ss 42-51. These provisions came into force on 1 April 2009: see the Housing (Scotland) Act 2006 (Commencement No 7, Savings and Transitional Provisions) Order 2009, SSI 2009/122.

${ }^{63}$ K G C Reid and G L Gretton, Conveyancing 2005 (2006) 124. 
The Commission's fourth and final factor was that owners are always free to repair their own property. In other words, although maintenance is not a duty on others, it is a right of those who are willing. In some cases owners may even be obliged to repair exclusive or common property, for example when they are bound by the terms of a standard security. However, this right sounds less heart-warming to owners when it is explained that they must meet the whole of the bill. Other owners are simply not liable unless there is a majority scheme decision authorising the repairs.

Consequently, none of the factors presented by the Scottish Law Commission sufficiently justifies the decision to avoid a positive duty of reasonable or necessary maintenance. As things stand, all is dependent on a majority of owners holding a reasonable view as to what needs to be done. Considering the generally small size of Scottish tenements, the possibility of deadlock is clear. When the legislation was going though the Scottish Parliament, it seems to have been thought that there could be recourse to the courts in the case of a minority initiative or a deadlock. ${ }^{64}$ If this was the true intention of the Parliament, however, it is nowhere to be found in the final enactment. The truth is that, in the absence of a duty of maintenance, not even a court can force an owner to agree to a repair, however reasonable, necessary or urgent it may be.

It may of course be argued that the right to prevent a repair is inherent in ownership, and no less important than the right to have the repair carried out. In terms of policy, however, this minimalistic approach seems to go against the repeated pleas of Scottish housing survey reports on the issue of disrepair. And in terms of legal principle, it is hard to see the harm in allowing courts to consider proposed repairs on their merits. Admittedly, people do not usually take their neighbours to court over repairs and would most likely give up in the face of opposition. Indeed the very low rate of litigation was claimed to show the success of the pre-reform common law. ${ }^{65} \mathrm{In}$ fact it is more plausibly attributable to the absence of a right to insist on repairs. One imagines that the pursuer in PS Properties would have preferred to go to court to have the repair sanctioned on grounds of reasonableness, had that been possible, than to take the extreme step of buying an additional unit in the building.

\section{(2) DMS and commonhold}

In contrast to the TMS, both the DMS and the English system of commonhold address the issue of a duty of maintenance, using the convenient agency of the management body corporate. Under the DMS there is an owners' association, run by a manager appointed by the owners; in commonhold there is a commonhold association, run by the board of directors. Both can readily carry the responsibilities of management and maintenance.

Under the DMS, the manager is directed to "manage the development for the benefit of the members". This includes a duty to inspect, and arrange maintenance of, such parts of the development as are subject to the scheme. ${ }^{66}$ For commonhold, by

\footnotetext{
${ }^{64}$ Scottish Parliament, Official Report, Justice 2 Committee, col 758 (27 April 2004).

${ }^{65}$ Scottish Parliament, Official Report col 10322 (16 Sept 2004; Mary Mulligan MSP, Deputy Minister for Communities).

${ }^{66}$ DMS r 8.
} 
contrast, maintenance is linked to the "commonhold community statement" (CCS) which is to be drawn up for each development: ${ }^{67}$

$<$ EXT $>$ The directors of a commonhold association shall, in particular, use any right, power or procedure conferred or created by virtue of section 37 for the purpose of preventing, remedying or curtailing a failure on the part of a unit-holder to comply with a requirement or duty imposed on him by virtue of the commonhold community statement or a provision of this Part. $<$ EXT $>$

A CCS must make provision in respect of insurance, maintenance and repair of commonhold flats and the common parts, ${ }^{68}$ and a model form with mandatory provisions is prescribed. ${ }^{69}$ This, however, is remarkably brief on the commonhold association's responsibility in respect of the common parts, imposing merely the obligation of "decorating them and putting them into sound condition", ${ }^{70}$ and it is completely silent in respect of the individual flats, leaving the matter to be determined by local rules. ${ }^{71}$ Admittedly, even these meagre duties may be more exacting than the common law concept of reasonable care. ${ }^{72}$ Nevertheless, it seems that the overall effectiveness of the arrangements will depend on the skill of draftsmanship of the local maintenance rules, for unless the association can point to a breach of a clearly imposed obligation, there is no basis for it to act against an individual owner. On the contrary, such an owner would be in the same position as any other freehold owner under English law, which largely allows properties to be left in disrepair.

In Scotland the DMS is better equipped to deal with irresponsible owners. Whatever its shortcomings, ${ }^{73}$ the statutory re-expression of common interest is of crucial importance for tenement buildings. ${ }^{74}$ It means that whenever support or shelter within the building is at risk, a statutory duty of repair falls on the owner of the part in question and is enforceable by any of the other owners. The absence from commonhold of an equivalent set of obligations imposes a steep learning curve on those who propose to adopt the new system. It is true that the official guidance notes recommend the inclusion of a provision in the CCS obliging owners to maintain their units, which would include decoration and putting the unit into a sound condition. ${ }^{75}$ But guidance of this sort is regrettably limited and brief. The result is scarcely satisfactory. On one hand, it is apparently imperative for commonhold associations to prescribe an appropriate set of rules, without which the schemes will inevitably fail over time. On the other hand, given that there are so few commonholds in operation

${ }^{67}$ Commonhold and Leasehold Reform Act 2002 s 35(2).

${ }^{68}$ Commonhold and Leasehold Reform Act 2002 s 26.

${ }^{69}$ Commonhold Regulations 2004, SI 2004/1829, reg 15. The model commonhold community statement (henceforth CCS) is set out in Sch 3.

${ }^{70}$ CCS para 4.5.1.

${ }^{71}$ CCS para 4.5.2.

${ }^{72}$ See for example, S M J Wong, "Potential pitfalls in the commonhold community statement and the corporate mechanisms of the commonhold association" (2006) Conv 14 at 20.

73 See C.(1)(c) above.

74 Tenements (Scotland) Act 2004 ss.7-9.

${ }^{75}$ Department for Constitutional Affairs, Commonhold: Guidance on the drafting a Commonhold Community Statement, including Specimen Local Rules (2005, available at http://www.dca.gov.uk/legist/commonhold/ccsguide.pdf) para 74. 
and no lawyer experienced in drafting the relevant rules, it is hardly surprising that most property developers have settled for the tried and tested system of long leasehold.

One may ask why the English reform chose to rely on the CCS and on local rules rather than, as in Scotland, imposing a statutory obligation of maintenance. Did the legislature believe that commonhold buildings could operate without the individual units being properly looked after? Or was there such confidence in the skills of conveyancers that they were expected to come up with the right set of rules first time round, and without any help from the legislator. ${ }^{76}$ By way of comparison, it may be noted that conveyancers in Scotland have had 200 years of experience in drafting positive burdens in relation to land.

\section{OCCUPIERS' LIABILITY}

Under commonhold, ownership of the common parts and the liability for their maintenance are united in the person of the commonhold association. In Scotland, the two are often severed: indeed this was one of the key ideas of the Scottish reform. It is instructive to test the effect of this severance in the context of occupiers' liability.

The Occupiers' Liability (Scotland) Act 1960 imposes a duty of care on all occupiers of premises. ${ }^{77}$ If, therefore, a person entering a tenement building suffers injury as a result of the breach of such a duty, a claim for damages will arise. An "occupier" is defined as "a person occupying or having control of land or other premises". 78 "Premises" are not limited to buildings but may include for example a path surrounding or leading up to a building. ${ }^{79}$ So if a postman is hit by a slate falling from the roof to the path, the owner of the roof is potentially liable for the injury.

The position may have been changed by the Tenements (Scotland) Act 2004. In the spirit of that reform, it seems that those who have voting power in scheme decisions relating to specific parts of the tenement also have some degree of "control" over those parts, regardless of ownership. For example, the default rule remains, as before, that the roof of a tenement building is owned by the top flat proprietor; ${ }^{80}$ but under the TMS the roof is maintained and paid for by all owners in the building, through making scheme decisions and contributions to scheme costs following a decision. ${ }^{81}$ Does a right to make decisions make the decision-makers liable under the 1960 Act as "occupiers of premises" in the event that objects fall from the roof due to poor maintenance and cause injuries to visitors or even trespassers? Prior to the Tenements Act, ownership of the roof carried the right and the risk at the same time. ${ }^{82}$

${ }^{76} \mathrm{G}$ Fetherstonhaugh, M Sefton and E Peters Commonhold (2004) para 4.9.2 attributed this approach to the parliamentary debate over the correct division of responsibilities for repair and maintenance, which led to no clear conclusion in view of the potential diversity in nature of all commonhold schemes.

${ }^{77}$ Occupiers' Liability (Scotland) Act 1960 s 2(1).

${ }^{78}$ Occupiers' Liability (Scotland) Act 1960 s 1(1).

${ }^{79}$ See for example J Blackie, "Liability as occupier to user of a right of way" 1994 SLT (News) 349.

${ }^{80}$ Tenements (Scotland) Act 2004 s 2(3).

${ }^{81}$ For the roof is, of course, "scheme property" under TMS r 1.2, and hence subject to the maintenance and payment provisions in rr 2-4.

${ }^{82}$ It was, however, quite common for a roof owned only by the top floor proprietor to be maintained by everyone by virtue of real burdens. 
In severing the link between ownership and maintenance, the Act has conferred new responsibility and, it may be, new liability as well.

If that is correct, there may be particular difficulties in the context of a failed proposal for maintenance. Take the case of a defective roof. If two out of four owners in the building propose a scheme decision for its repair and the other two object, no scheme decision can be made. And because there is no overarching duty of maintenance, those in favour of the repair have their hands tied. If they happen to own the roof, they can repair it anyway but at their own expense. Alternatively, they may argue that the shelter to the tenement is at risk and that the repair must go ahead under the relevant statutory provision. ${ }^{83}$ Not all defects in a roof, however, are detrimental to shelter. Two or three dangerously-placed slates or ornamental structure will not expose the building to the weather. However, they can kill if they fall. Yet there is nothing much that a person who was outvoted can do to prevent this.

Where, then, does liability lie? Are all four owners liable as 1960 Act "occupiers" on the basis that, together, they have "control" over repairs? And if so, does the position depend on the voting stance of individuals? Is voting against a scheme decision a ground for blame or voting in favour a reason to be exonerated? The potential liability may be considerable. In a case from Hong Kong, a concrete canopy of an apartment building collapsed and fell on to the pavement below, injuring seven passers-by and killing one. ${ }^{84}$ Although most of the owners in the building had never set foot on to the part in question, they were all called upon to pay for the damages awarded, each being liable for about $£ 15,000$. It is unclear what would happen if a similar incident occurred in a Scottish tenement, many of which have only six or eight flats. It may of course be argued that an effective insurance policy will avert any serious problem. But while insurance is now a requirement for all tenements in Scotland, injury to third parties is not among the prescribed risks. ${ }^{85}$ And in any case one suspects that those tenements in which owners vote against reasonable repairs are also those tenements in which there is a higher incidence of disrepair, injury to the public, and absence of insurance.

As things stand, the TMS does not send out a clear enough signal as to the consequences of objecting to a repair of property which is not owned. Will the negligent exercise, or more likely non-exercise, of repairing rights open the way to unexpected liability? After all, does anyone expect rights without responsibility in any developed jurisdiction? Presumably there was no intention to change the law in this respect; but by introducing a right of control over property which belongs to someone else, the TMS may not have fully engaged with the corresponding duty or responsibility.

In principle the same criticism might be made of the DMS, but in practice the system of management will usually prevent cases of significant disrepair. For repairs are undertaken by the manager acting alone, ${ }^{86}$ unlike in the TMS which works by a series of ad hoc scheme decisions. The only possible concern is the requirement that the manager must comply with the directions given by the owners' association at a

${ }^{83}$ Tenements (Scotland) Act 2004 s 8. Just occasionally, it may be possible to use the provisions for emergency repairs contained in TMS $\mathrm{r} 7$.

${ }^{84}$ Tse Lai Yin v Incorporated Owners of Albert House [1999] HKEC 825.

${ }^{85}$ Tenements (Scotland) Act 2004 s18; Tenements (Scotland) Act 2004 (Prescribed Risks) Order 2007, SSI 2007/16.

${ }^{86}$ DMS r 8(b). 
general meeting, ${ }^{87}$ which might presumably include a direction not to carry out a repair. In the event of injury actually occurring, the owners' association and its manager are well-equipped to determine and to apportion liability.

Specific legislative provision can be of help here. In Ontario, for example, the management corporation alone is deemed the occupier of the common elements for the purposes of occupiers' liability. ${ }^{88}$ The same may already be true in practice under the DMS. In this respect among others the DMS achieves the clear, logical and fair allocation of rights and responsibilities which sometimes eludes the TMS.

\section{E. DMS AND COMMONHOLD COMPARED}

\section{(1) The bodies corporate}

A significant advantage of the DMS over commonhold is its choice of legal person for the body corporate. In the DMS the owners' association is a sui generis body corporate created by legislation. ${ }^{89}$ In contrast, and despite the Aldridge Committee's recommendation to the contrary, ${ }^{90}$ the commonhold reform opted for a company limited by guarantee. This has been one of the most controversial topics in the limited debate that has so far taken place about commonhold. Quite apart from anything else, this area of company law is undeveloped, with many unresolved difficulties and uncertainties. ${ }^{91}$ Introducing a system of landownership with which no conveyancer had experience on the basis of a company law concept unfamiliar to most company lawyers was perhaps an overly ambitious project in a jurisdiction such as England which already had the well-established and familiar alternative of leasehold title.

The label of a company limited by guarantee is also potentially misleading. Although the upper limit of the liability of each unit owner is set by statute at $£ 1$, this may not reflect the true position should the company actually become insolvent. As has been observed, a unit owner in commonhold has the dual status of being both a member of the company and also a person who receives its services. ${ }^{92}$ This may render the notion of limited liability "fictional". 93 The DMS in comparison avoids such confusion or even unintentional disinformation by clearly defining the liability of owners against claims from creditors. ${ }^{94}$

Furthermore, the problems of adopting mainstream company law may run deeper than simple unfamiliarity or uncertainty. For example, the commonhold association is to be run by a board of directors and there must be a minimum of two, in line with UK

${ }^{87}$ DMS r 4.7.

${ }^{88}$ Condominium Act 1998 s 26.

${ }^{89}$ Title Conditions (Scotland) Act 2003 (Development Management Scheme Order) 2009 art 4(2).

${ }^{90}$ Commonhold: Freehold Flats (n 12) para 8.12.

${ }^{91}$ L Crabb, "The Commonhold and Leasehold Reform Act 2002: a company law perspective" (2004) Company Lawyer 213. Only one provision in the Companies Act $2006-$ s 1283 - is exclusively concerned with the commonhold association.

${ }^{92}$ Crabb (n 91).

${ }^{93}$ Wong (n 72) at 33.

94 Title Conditions (Scotland) Act 2003 (Development Management Scheme) Order 2009 pt 4. 
company law. ${ }^{95}$ The DMS, by contrast, is run by a single manager. In a medium to small development, the availability and costs of personnel are likely to be significant factors.

\section{(2) Conduct standard for directors and managers}

Another issue is the standard of conduct expected of directors or managers. In most jurisdictions only reasonable care is required from persons in the position of managing apartment developments, especially those elected from among the owners. ${ }^{96}$ Indeed, to encourage participation by owners in the scheme, the emphasis is on honesty and reasonableness of action rather than on skills or knowledge. In British Columbia, the person must act honestly and in good faith, exercising the care, diligence and skill of a reasonably prudent person. ${ }^{97}$ In Singapore, the person must act honestly and use reasonable diligence in the discharge of the duties. ${ }^{98}$ In South Africa ${ }^{99}$ and New South Wales, ${ }^{100}$ such persons owe fiduciary duties to the body corporate, to avoid conflicts of interest and so on. Although there is no statutory guidance in Scotland, some equivalent standard can presumably be expected of the manager of a DMS.

The position in England is necessarily different. In addition to the requirement of honesty and other fiduciary duties, there is also the element of skill or knowledge expected of company directors. In that connection section 174 of the Companies Act 2006 provides that:

$<$ EXT $>$

(1) A director of a company must exercise reasonable care, skill and diligence.

(2) This means the care, skill and diligence that would be exercised by a reasonably diligent person with -

(a) the general knowledge, skill and experience that may reasonably be expected of a person carrying out the functions carried out by the director in relation to the company, and

(b) the general knowledge, skill and experience that the director has. $<$ EXT $>$

As well as mere honesty and diligence, therefore, a director will be held to the skill and experience that he or she has personally. In other words, this is a subjective test, varying the standard to accommodate the differences from one person to another. While this is an accepted approach in mainstream company law, it is likely to be unhelpful in the context of commonhold. Unlike other companies, commonhold associations are set up with the sole business of managing their members' home. ${ }^{101}$

${ }^{95}$ Commonhold Regulations 2004 Sch 2 para 38.

${ }^{96}$ Van der Merwe (n 4) at para 381.

${ }^{97}$ Strata Property Act 1998 s 31.

${ }^{98}$ Building Maintenance and Strata Management Act 2004 s 61(1).

${ }^{99}$ Sectional Titles Act 1986 s 40(1).

${ }^{100}$ Re Steel and the Conveyancing (Strata Titles) Act 1961 (1968) 88 WN (pt 1) 467.

${ }^{101}$ In the same vein, the DMS association is expressly prohibited from carrying on any trade whether or not for profit: see DMS r 3.3. 
Ideally, therefore, some of the directors should come from the ranks of the members. Requiring a person to demonstrate the same level of skill and experience as in his fulltime employment as, for instance, a solicitor or a director of a trading company, is certainly a deterrent to anyone considering taking the job. Yet if the more relevantly skilled owners in a commonhold are unwilling to act because they will be held to a higher standard of skill and expertise, this can only lead to one of two outcomes. Either the commonhold will be entrusted to owners who have little or no experience of management or running a company or maintaining property, or professionals must be employed to fill the void of knowledge and skills. The cost of the latter option which, given the complexity of commonhold, is likely to be considerable - will, of course, have to be met by the owners. From this it is all too easy to conclude that commonhold is neither cheaper nor more convenient than the system of leasehold which it was intended to replace.

As already seen, ${ }^{102}$ the commonhold legislation is slow to impose duties on owners, especially with regard to individual units. And so the reform attempted to conjure up a body corporate with all kinds of duties but considerably fewer powers a body which must carry most of the burden of the maintenance and management of a building at a standard expected of a trading company. In other words, the commonhold system expects a management body which is either too good to be true, or too expensive to be appealing. In contrast, the DMS takes a much more realistic approach in balancing benefits and costs.

\section{(3) Dispute resolution}

Another reflection of this difference of mentality may be seen in relation to dispute resolution. Appreciating the importance of harmony and sense of community within a development, the commonhold framework admirably emphasises alternative dispute resolution where possible. Thus when faced with a dispute, the commonhold association and owners "must first consider" and then "reconsider" "resolving the matter" by direct negotiation or "using arbitration, mediation, conciliation or any other form of dispute resolution procedure involving a third party, other than legal proceedings". ${ }^{103}$ Despite the best of intentions, however, the ambition of these rules seems matched only by their vagueness. There is considerable uncertainty as to the precise nature of such consideration and reconsideration, the scope of resolution mechanisms to be considered, the validity of legal proceedings without such consideration, the identity of such third party, and so on. Once again the legislator expects individual schemes to come up with practical and workable solutions tailored to their needs, without taking into account the difficulty of starting a completely new structure from scratch. And with so few schemes in existence, where should one turn for expertise on dispute resolution for commonhold matters?

In contrast the DMS structure adopts the thoroughly practical approach of appointing the Lands Tribunal for Scotland in charge of certain disputes, ${ }^{104}$

\footnotetext{
${ }^{102}$ See C.(2) above.

${ }^{103}$ CCS paras 4.11.4, 4.11.7, 4.11.12, 4.11.15, 4.11.19, 4.11.29.

104 Title Conditions (Scotland) Act 2003 (Development Management Scheme) Order 2009 pt 7.
} 
supplemented by clearly defined criteria for applications to the sheriff court. ${ }^{105}$ Rather than promoting the idea of alternative dispute resolution, the DMS opts to rely on established specialist bodies. It seems likely that such certainty and familiarity will be welcomed in practice, in preference to the English approach of starting everything on a blank sheet of paper with the best of ideals and the scarcest of details.

\section{F. CONCLUSION}

The Development Management Scheme provides an exciting point in the continuing reform of property law in Scotland. In the context of tenement buildings, it brings the experienced Scots law much more in line with the approach adopted by many other jurisdictions around the world.

Naturally, the DMS had certain disadvantages when compared to the, currently much more prevalent, Tenement Management Scheme. The latter operates on an informal basis well-suited to small developments with no frequent or ongoing concerns. The DMS, inevitably, is more complex and more costly. However, even in developments of moderate size, the advantages of DMS may outweigh its disadvantages by achieving a realistic and practical allocation of rights and responsibilities. Superficially, the TMS is about empowerment, construing rights with little regard to the corresponding responsibilities. In comparison, both rights and duties are much more tangible under DMS, and much more visible and ascertainable by reference to the owners' association and the manager.

The initially unsuccessful experience of commonhold in England sheds useful light on the future path of the DMS. Both concepts, contemplated for many years before eventual introduction, share many features in common, offering a voluntary alternative to an often-criticised traditional model. Possibly fatefully, commonhold opted for the unhelpful medium of a company limited by guarantee and has struggled from the very beginning. The DMS managed to stand firm on the ground of a tailormade body corporate, while adhering to the usual Scottish approach of offering much flexibility to owners and developers.

It will be interesting to see the impact of the Development Management Scheme on the law of the tenement in Scotland. In the meantime, if the initiative is successful, it may prompt a re-think in England on this increasingly pressing issue of an effective system for flat ownership on a congested island.

105 Title Conditions (Scotland) Act 2003 (Development Management Scheme) Order 2009 pt 5 . 